\title{
Nutrient Uptake and Soil Health as Influenced by Plant Density and Age of Seedlings of Rice (Oryza sativa L.) under Modified SRI Method of Planting
}

\author{
M. R. Nandhakumar ${ }^{1 *}$, K. Velayudham ${ }^{2}$ and N. Thavaprakaash ${ }^{3}$ \\ ${ }^{1}$ Department of Crop Management, Vanavarayar Institute of Agriculture (TNAU), Pollachi, \\ Tamil Nadu, India \\ ${ }^{2}$ Director (Rtd.,), Directorate of Crop Management, Tamil Nadu Agricultural University, \\ Coimbatore, Tamil Nadu, India \\ ${ }^{3}$ Directorate of Crop Management (Agronomy), Tamil Nadu Agricultural University, \\ Coimbatore, Tamil Nadu, India \\ *Corresponding author
}

\section{A B S T R A C T}

\section{Keywords}

Plant density,

Seedling age,

Nutrient uptake,

Available NPK

\section{Article Info}

Accepted:

22 July 2020

Available Online:

10 August 2020
Field experiments were carried out at Tamil Nadu Agricultural University, Coimbatore, India during samba (August-December) seasons of 2012 and 2013 to find out the optimum crop geometry, age and number of seedlings on growth and physiological characters in relation to yield of low land rice. The experiment consisted of three mainplot treatments viz., $\mathrm{M}_{1}-25 \times 25$ $\mathrm{cm}, M_{2}-25 \times 20 \mathrm{~cm}$ and $M_{3}-25 \times 15 \mathrm{~cm}$ and six sub-plot treatments $S_{1}-14$ day old seedlings (DOS)+1 seedling/hill, $\mathrm{S}_{2}-14$ DOS +2 seedlings/hill, $\mathrm{S}_{3}-$ 14 DOS +3 seedlings/hill, $\mathrm{S}_{4}-21$ DOS+1 seedling/hill, $\mathrm{S}_{5}-21$ DOS +2 seedlings/hill and $\mathrm{S}_{6}-21$ DOS+3 seedlings/hill and replicated thrice in a split plot design. The treatment combination of $\mathrm{M}_{3} \mathrm{~S}_{5}(25 \times 15 \mathrm{~cm}$ spacing and 21 DOS with two seedlings hill $^{-1}$ ) recorded higher nitrogen uptake than others at panicle initiation, flowering and harvest stages. The same trend was followed on phosphorus and potassium also.

\section{Introduction}

Rice is an important staple food that provides $66-70 \%$ of body calorie intake of the consumers (Barahand Pandey, 2005). To assure food security in the rice consuming countries of the world, rice production should be increased by $50 \%$ in these countries by 2025. This additional rice will have to be produced on less land with less water, labour and chemicals (Zheng et al., 2004). Similarly, to achieve the projected targets of 680 and 771 million tonnes (Mt) by 2015 and 2030, respectively, the productivity of rice has to be 
increased through adoption of suitable technologies (Badawi, 2004). The system of rice intensification (SRI) is a new methodology for increasing the productivity of irrigated rice by changing the management of plants, soil, water and nutrients resulting in both healthy soil and plants, supported by greater root growth and the soil microbial abundance and diversity (Kumar and Shivay 2004; Weijabhandara, 2011).

Fertilizer is the major input and one of the most important factors in rice production. Good fertilizer management can increase rice yield and reduce production cost. It is required to supply the nutrient requirements for plants and to attain high performance in the rice plant Practice of proper management strategies like adequate rate and timing of fertilizer application can increase rice yield and influence cost of production. Nitrogen $(\mathrm{N})$, phosphorus $(\mathrm{P})$, and potassium $(\mathrm{K})$ are applied as fertilizers in large quantities to rice fields, and a deficiency of either of the nutrient leads to yield losses are many factors that influence the nutrient absorption including cultivar, soil type, fertilizer type, fertilization technology, and environmental factors. Imbalanced N, P, and $\mathrm{K}$ fertilization application can affect soil productivity. (Amit Kumar et al., 2018).

However, rate of fertilizer application is also governed by socio-economic factors. Such factors are production cost, economic situation of the farmers, efficiency of extension service, and availability of credit to the growers. Use of adequate NPK rate is important not only for obtaining maximum economic return, but also to reduce environmental pollution. Therefore, the study was conducted to investigate nutrient uptake and soil health as influenced by plant density and age of seedlings of rice (Oryza sativa L.) under modified SRI method of planting.

\section{Materials and Methods}

Field experiments were carried out at Tamil Nadu Agricultural University, Coimbatore, India during samba (August - December) season of 2012 and 2013. Coimbatore is situated in the Western agro-climatic zone of Tamil Nadu at $11^{\circ} \mathrm{N}$ latitude and $77^{\circ} \mathrm{E}$ longitude and at an altitude of $426.7 \mathrm{~m}$ above mean sea level. The soil of the experimental field was clay loam in texture belonging to Typic Haplustalf with low in available $\mathrm{N}$ (199.0 and $207.519 \mathrm{~kg} \mathrm{ha}^{-1}$ ), low in available $\mathrm{P}$ (9.0 and $\left.11.0 \mathrm{~kg} \mathrm{ha}^{-1}\right)$ and high in available

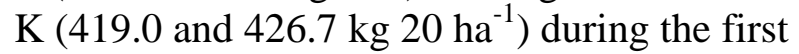
and second years, respectively. International pipette method (Piper, 1966), Alkaline Permanganate method (Subbiah and Asija, 1956), Olsen's method (Olsen et al., 1954) and Neutral Normal Ammonium Acetate (Stanford and English, 1949) for analyzing Soil texture, available nitrogen, phosphorus and potassium, respectively. The experiments consisted of three main-plot treatments viz., $\mathrm{M}_{1}-25 \times 25 \mathrm{~cm}, \mathrm{M}_{2}-25 \mathrm{x} 20 \mathrm{~cm}$ and $\mathrm{M}_{3}-25$ $\mathrm{x} 15 \mathrm{~cm}$ and six sub-plot treatments, $\mathrm{S}_{1}-14$ Day Old Seedlings (DOS) +1 seedling hill ${ }^{-1}$, $\mathrm{S}_{2}-14 \mathrm{DOS}+2$ seedlings hill ${ }^{-1}, \mathrm{~S}_{3} 14 \mathrm{DOS}+$ 3 seedlings hill $^{-1}, \mathrm{~S}_{4}-21 \mathrm{DOS}+1$ seedling hill $^{-1}, \mathrm{~S}_{5}-21$ DOS +2 seedlings hill ${ }^{-1}$ and $\mathrm{S}_{6}-$ $21 \mathrm{DOS}+3$ seedlings hill ${ }^{-1}$. The treatments are replicated thrice in a split-plot design; the rice variety $\mathrm{CO}(\mathrm{R}) 50$ with field duration of 135 days was used in the trial. Separate nurseries were raised for conventional and SRI method of planting to transplant 21 and 14 DOS, respectively. All other package of practices were carried out as per recommendation of CPG (2012). Soil samples were collected from $0-20 \mathrm{~cm}$ depth at random from the experimental field prior to sowing. The collected samples were shade dried, powdered and sieved through $2 \mathrm{~mm}$ sieve. The soil samples were analyzed for texture, $\mathrm{pH}$, EC, organic carbon content, available nitrogen, phosphorus and potassium. The 
available $\mathrm{N}, \mathrm{P}$ and $\mathrm{K}$ were expressed in $\mathrm{kg}$ $\mathrm{ha}^{-1}$ and the organic carbon content was expressed in $\mathrm{g} \mathrm{kg}^{-1}$. Post harvest soil samples were also collected plot-wise from a depth of $0-20 \mathrm{~cm}$ and analyzed the available N, P and $\mathrm{K}$. Methods adopted for analysis of the soil samples are indicated in Table 1.

\section{Results and Discussion}

\section{Nitrogen uptake (Table 2)}

The nitrogen uptake $\left(\mathrm{kg} \mathrm{ha}^{-1}\right)$ by rice was increased with the crop growth. The pooled statistical analysis at different stages indicated that the crop geometry, age and number of seedlings exerted significant influence on $\mathrm{N}$ uptake of rice.

The closer crop geometry of $25 \times 15 \mathrm{~cm}\left(\mathrm{M}_{3}\right)$ recorded significantly more nitrogen uptake (29.7, 75.8, 100.1 and $106.9 \mathrm{~kg} \mathrm{ha}^{-1}$ ) at tillering, panicle initiation, flowering and harvest stages, respectively than $\mathrm{M}_{2}(25$ x 20 $\mathrm{cm})$ and $\mathrm{M}_{1}(25 \times 25 \mathrm{~cm})$. Wider spacing of 25 x $25 \mathrm{~cm}\left(\mathrm{M}_{1}\right)$ resulted in the least nitrogen uptake $\left(24.7,61.8,85.3\right.$ and $\left.87.8 \mathrm{~kg} \mathrm{ha}^{-1}\right)$ at tillering, panicle initiation, flowering and harvest stages, respectively.

At tillering stage, conspicuously more nitrogen uptake $\left(32.1 \mathrm{~kg} \mathrm{ha}^{-1}\right)$ was observed with 21 DOS with three seedlings hill ${ }^{-1}\left(\mathrm{~S}_{6}\right)$ over others. Transplanting of 14 day aged seedlings with one seedling hill ${ }^{-1}\left(S_{1}\right)$ resulted the least nitrogen uptake $\left(22.4 \mathrm{~kg} \mathrm{ha}^{-1}\right)$.

At panicle initiation stage, 14 DOS with one seedling hill ${ }^{-1}\left(\mathrm{~S}_{1}\right)$ foraged higher $\mathrm{N}(73.0 \mathrm{~kg}$ $\left.\mathrm{ha}^{-1}\right)$ over others and was on par with $\mathrm{S}_{5}(21$ DOS with two seedlings hill ${ }^{-1}$ ). Invariably, 21 DOS with three seedlings hill $^{-1}\left(\mathrm{~S}_{6}\right)$ had showed the lowest response with regard to nitrogen uptake $\left(65.6 \mathrm{~kg} \mathrm{ha}^{-1}\right)$. Similar trend was followed at flowering and harvest stages of rice growth.
Crop geometry, age and number of seedlings had significant interaction on $\mathrm{N}$ uptake at all the crop growth stages during both the years. At tillering stage, seedling age of 21 day old with three seedlings hill ${ }^{-1}$ planted at closer spacing of $25 \times 15 \mathrm{~cm}\left(\mathrm{M}_{3} \mathrm{~S}_{6}\right)$ registered higher nitrogen uptake $\left(36.1 \mathrm{~kg} \mathrm{ha}^{-1}\right)$ than other combination of treatments and was on par with $\mathrm{M}_{2} \mathrm{~S}_{6}$ and $\mathrm{M}_{3} \mathrm{~S}_{3}$. The lowest nitrogen uptake $\left(20.8 \mathrm{~kg} \mathrm{ha}^{-1}\right)$ was noted with $\mathrm{M}_{1} \mathrm{~S}_{1}(25$ x $25 \mathrm{~cm}$ and 14 DOS with one seedling hill ${ }^{-1}$ ).

In pooled analysis, at panicle initiation, flowering and harvest stages, $\mathrm{M}_{3} \mathrm{~S}_{5}(25 \times 15$ $\mathrm{cm}$ spacing and 21 DOS with two seedlings hill $^{-1}$ ) recorded higher nitrogen uptake (83.2, 113.1 and $116.3 \mathrm{~kg} \mathrm{ha}^{-1}$, respectively) than others. It was comparable with $\mathrm{M}_{3} \mathrm{~S}_{3}$ and $\mathrm{M}_{2} \mathrm{~S}_{1}$ at panicle initiation stage, $\mathrm{M}_{1} \mathrm{~S}_{1}, \mathrm{M}_{2} \mathrm{~S}_{1}$, $\mathrm{M}_{2} \mathrm{~S}_{5}$ and $\mathrm{M}_{3} \mathrm{~S}_{5}$ at flowering and harvest stages. Wider spacing of $25 \times 25 \mathrm{~cm}$ and age old seedling of 21 days with three seedlings $\left(\mathrm{M}_{1} \mathrm{~S}_{6}\right)$ resulted the lowest nitrogen uptake (49.9, 71.6 and $81.9 \mathrm{~kg} \mathrm{ha}^{-1}$ ) at panicle initiation, flowering and harvest stages, respectively.

\section{Phosphorus uptake (Table 3)}

Effect of crop geometry, age and number of seedlings brought out a significant influence on P uptake of rice at different stages during the course of experimentations. In pooled analysis, the uptake of $\mathrm{P}$ recorded higher values $\left(7.7,16.6,21.1\right.$ and $\left.26.4 \mathrm{~kg} \mathrm{ha}^{-1}\right)$ in $\mathrm{M}_{3}$ $(25 \times 15 \mathrm{~cm})$ at tillering, panicle initiation, flowering and harvest stages, respectively than others. Rice transplanted at $25 \times 25 \mathrm{~cm}$ spacing $\left(\mathrm{M}_{1}\right)$ recorded the lowest $\mathrm{P}$ uptake (4.5, 10.0, 16.1 and $\left.19.2 \mathrm{~kg} \mathrm{ha}^{-1}\right)$ at tillering, panicle initiation, flowering and harvest stages, respectively.

Age and number seedlings also had significant influence on $\mathrm{P}$ uptake. At tillering stage, seedling age of 14 days with three 
seedlings hill ${ }^{-1}\left(\mathrm{~S}_{3}\right)$ recorded higher $\mathrm{P}$ uptake $\left(7.3 \mathrm{~kg} \mathrm{ha}^{-1}\right)$ than other age and number of seedlings. The lowest $\mathrm{P}$ uptake $\left(4.9 \mathrm{~kg} \mathrm{ha}^{-1}\right)$ was recorded in $\mathrm{S}_{1}$ (14 DOS with one seedling hill ${ }^{-1}$ ).

At panicle initiation stage, distinctly higher phosphorus uptake $\left(15.2 \mathrm{~kg} \mathrm{ha}^{-1}\right)$ was noticed with 21 DOS with two seedlings hill $^{-1}\left(\mathrm{~S}_{5}\right)$ and it was comparable with $\mathrm{S}_{1}$ (14 DOS with one seedling hill $\left.^{-1}\right)$. The lowest phosphorus uptake $\left(12.5 \mathrm{~kg} \mathrm{ha}^{-1}\right)$ was witnessed with 21 DOS combined with three seedling hill $^{-1}\left(\mathrm{~S}_{6}\right)$. Similar results were followed at flowering and harvest stages also.

The interaction effect between crop geometry, age and number of seedlings was significant on P uptake at different stages during both the years. At tillering stage, the combination of closer spacing $25 \times 15 \mathrm{~cm}$ and 14 DOS with three seedlings hill $^{-1}\left(\mathrm{M}_{3} \mathrm{~S}_{3}\right)$ was found to record higher $\mathrm{P}$ uptake $\left(9.0 \mathrm{~kg} \mathrm{ha}^{-1}\right)$ and it was at par with $\mathrm{M}_{3} \mathrm{~S}_{6}$ than others. The lowest $\mathrm{P}$ removal $\left(3.6 \mathrm{~kg} \mathrm{ha}^{-1}\right)$ was observed in combination of $\mathrm{M}_{1} \mathrm{~S}_{1}(25 \times 25 \mathrm{~cm}$ and 14 DOS with one seedling hill $^{-1}$ ).

Closer spacing of $25 \times 15 \mathrm{~cm}$ and 21 DOS with two seedlings hill ${ }^{-1}\left(\mathrm{M}_{3} \mathrm{~S}_{5}\right)$ recorded higher phosphorus uptake $(18.9,24.5$ and $29.8 \mathrm{~kg} \mathrm{ha}^{-1}$ ) at panicle initiation, flowering and harvest stages, respectively and was comparable with $\mathrm{M}_{3} \mathrm{~S}_{3}$ at panicle initiation, $\mathrm{M}_{2} \mathrm{~S}_{1}$ and $\mathrm{M}_{3} \mathrm{~S}_{3}$ at flowering, $\mathrm{M}_{2} \mathrm{~S}_{1}$ and $\mathrm{M}_{2} \mathrm{~S}_{5}$ at harvest stages. The lowest phosphorus uptake $\left(7.7,12.3\right.$ and $\left.14.2 \mathrm{~kg} \mathrm{ha}^{-1}\right)$ was evident with wider spacing of $25 \times 25 \mathrm{~cm}$ in association of 21 DOS with three seedlings hill $^{-1}\left(\mathrm{M}_{1} \mathrm{~S}_{6}\right)$ at panicle initiation, flowering and harvest stages, respectively.

\section{Potassium uptake (Table 4)}

During these experiments, transplanting of rice with $25 \times 15 \mathrm{~cm}$ spacing $\left(\mathrm{M}_{3}\right)$ recorded distinctly higher potassium uptake (15.0, 51.4, 84.3 and $98.6 \mathrm{~kg} \mathrm{ha}^{-1}$ ) at tillering, panicle initiation, flowering and harvest stages, respectively than others. Whereas, wider spacing of $25 \times 25 \mathrm{~cm}\left(\mathrm{M}_{1}\right)$ recorded lucidly the lowest potassium uptake $(12.5,39.5,72.0$ and $81.6 \mathrm{~kg} \mathrm{ha}^{-1}$ ) at tillering, panicle initiation, flowering and harvest stages, respectively.

Age and number of seedlings had marked influence on the $\mathrm{K}$ uptake at all the stages of observation. At tillering stage, 14 DOS with three seedlings hill ${ }^{-1}\left(\mathrm{~S}_{3}\right)$ recorded higher $\mathrm{K}$ uptake $\left(16.8 \mathrm{~kg} \mathrm{ha}^{-1}\right)$ these experiments than other treatments. The lowest K uptake (11.2 $\mathrm{kg} \mathrm{ha}^{-1}$ ) was registered with $\mathrm{S}_{1}$ (14 DOS with one seedling hill $\left.^{-1}\right)$. Whereas, at panicle initiation stage, $S_{1}$ (14 days with one seedling hill $^{-1}$ ) was registered perceptibly higher potassium uptake $\left(51.9 \mathrm{~kg} \mathrm{ha}^{-1}\right)$ during these study and was on par with $\mathrm{S}_{5}$. Transplanting of 21 day old seedlings with three seedlings hill $^{-1} \quad\left(\mathrm{~S}_{6}\right)$ recorded the lowest potassium uptake $\left(38.0 \mathrm{~kg} \mathrm{ha}^{-1}\right)$. Similar results were reported at flowering and harvest stages of rice too.

A significant interaction effect was observed between crop geometry, age and number of seedlings at all stages of observations during both the years. At tillering stage, rice transplanted at $25 \times 15 \mathrm{~cm}$ and 21 DOS with three seedlings hill $^{-1} \quad\left(\mathrm{M}_{3} \mathrm{~S}_{6}\right)$ recorded significantly higher $\mathrm{K}$ uptake $\left(17.8 \mathrm{~kg} \mathrm{ha}^{-1}\right)$ compared to all other treatment combinations. It was comparable with $\mathrm{M}_{2} \mathrm{~S}_{3}, \mathrm{M}_{2} \mathrm{~S}_{6}$ and $\mathrm{M}_{1} \mathrm{~S}_{3}$. The lowest $\mathrm{K}$ uptake $\left(9.0 \mathrm{~kg} \mathrm{ha}^{-1}\right)$ was recorded under the treatment combination of $\mathrm{M}_{1} \mathrm{~S}_{1}(25 \times 25 \mathrm{~cm}$ and 14 DOS with one seedling hill $\left.{ }^{-1}\right)$.

At later stages (panicle initiation, flowering and harvest stages), obviously higher $\mathrm{K}$ uptake (62.1, 98.9 and $119 \mathrm{~kg} \mathrm{ha}^{-1}$, respectively) was observed in $\mathrm{M}_{3} \mathrm{~S}_{5}(25 \times 15$ 
$\mathrm{cm}$ and 21 DOS with two seedlings hill ${ }^{-1}$ ) and was comparable with $\mathrm{M}_{2} \mathrm{~S}_{1}$ at panicle initiation stage; and $\mathrm{M}_{2} \mathrm{~S}_{1}, \mathrm{M}_{2} \mathrm{~S}_{5}$ and $\mathrm{M}_{3} \mathrm{~S}_{4}$ at flowering stage. Crop geometry of $25 \times 25 \mathrm{~cm}$ and 21 DOS with three seedlings hill ${ }^{-1}\left(\mathrm{M}_{1} \mathrm{~S}_{6}\right)$ recorded the least potassium uptake (30.3, 53.5 and $58.7 \mathrm{~kg} \mathrm{ha}^{-1}$ ) at panicle initiation, flowering and harvest stages, respectively.

Influence of crop geometry, age and number of seedlings on nutrient uptake of rice

Nitrogen is very essential for the growth and development of crops, it enhances biomass and seed yield subject to the efficient water supply. Nitrogen absorbed by rice during the vegetative growth stages contributed to growth during reproduction and grain-filling through translocation (Norman et al., 1992; Bufogle et al., 1997).

Drymatter production and its conversion to economic yield is a cumulative effect of various physiological processes occurring during the life cycle of plants. An increase in yield of rice with increasing rate of nitrogen has been reported earlier Khan et al., (1994). Nitrogen uptake differed significantly due to various levels of planting geometry at all the growth stages during both years. The closer spacing of $25 \times 15 \mathrm{~cm}$ favoured in crop to absorbed more amount of $\mathrm{N}$ throughout the growth stages (Fig. 1). Higher biomass gain and total above ground $\mathrm{N}$ content were the driving factors for $\mathrm{N}$ uptake. The results are in conformity with the findings of Borkar et al., (2008). Similarly, P and K uptake was also higher with $25 \times 15 \mathrm{~cm}$ spacing compared to others at all the growth stages during the course of experimentation (Fig. 1). The discussion made for $\mathrm{N}$ uptake holds good here also. This is in conformity with the findings of Bezbaruha et al., (2011); Amit Kumar et al., (2018).
Age and number of seedlings had significant influence on the $\mathrm{N}$ uptake by the crop at all growth stages. At initial tillering stage, 21 day old three seedlings hill $^{-1}$ produced higher DMP and more $\mathrm{N}$ concentration in biomass that have increased nutrient uptake. At later stages, 14 day old one seedling hill ${ }^{-1}$ and which was on par with 21 day old two seedlings hill ${ }^{-1}$ in term of $\mathrm{N}, \mathrm{P}$ and $\mathrm{K}$ uptake (Fig. 1). This might be due to enhanced root activity as evidenced from lengthier roots subsequently increased nutrient uptake and total DMP. Higher uptake was mainly attributed to the better root activity and increased DMP besides less competition among plants.

Perhaps profuse and robust root system due to early seedling vigour might have facilitated greater ability to mobilize more nutrients, concomitant with higher absorption and translocation of nutrients. A well developed and healthy root system plays an important role in uptake ( $\mathrm{N}, \mathrm{P}$ and $\mathrm{K})$ and translocation of nutrients from soil particularly with planting younger seedlings (Gobi et al., 2019).

Younger seedling with better root activity supplied essential nutrients for the plant, which ultimately increased the nutrient uptake. Similar findings were made by Sridevi (2006). Transplanting younger seedlings i.e., less than 15 day old seedlings had higher tillering capacity and more vigour which in turn helped in extracting nutrients from soil (Manjunatha et al., 2010).

\section{Interaction effect of treatments on nutrient uptake of rice}

Interaction effect between crop geometry, age and number of seedlings was significant on $\mathrm{N}$ uptake at all growth stages. Rice planted at 25 x $15 \mathrm{~cm}$ with 21 day old three seedlings hill ${ }^{-1}$ removed higher amount of $\mathrm{N}$ compared to 
other combinations at initial stage. At later stages, combination of $25 \times 15 \mathrm{~cm}$ spacing and 21 day old two seedlings hill ${ }^{-1}$ had better $\mathrm{N}$ uptake. Higher LAI and increased tillers unit area $^{-1}$ exhibited higher biomass and in turn influenced the vegetative $\mathrm{N}$ uptake. This result was confirmed with Nandhakumar et al., (2016). Planting two seedlings hill $^{-1}$ recorded higher nutrient uptake than others and it was mainly attributed to better root activity and increased drymatter production. Similar findings are made by Bommayasamy et al., (2020). Similarly, combination of $25 \mathrm{x}$ $15 \mathrm{~cm}$ spacing and 21 day old two seedlings hill $^{-1}$ had significantly increased the $\mathrm{P}$ and $\mathrm{K}$ uptake at panicle initiation, flowering and harvest stages during both the years of study. The detailed discussion made for $\mathrm{N}$ uptake holds good here too.

Table.1 Details of analytical methods employed in soil analysis

\begin{tabular}{|c|c|c|}
\hline Particulars & Methods & References \\
\hline \multicolumn{3}{|l|}{ I. Mechanical composition } \\
\hline Textural analysis & International pipette method & Piper (1966) \\
\hline \multicolumn{3}{|l|}{ II. Soil Chemical Analysis } \\
\hline $\begin{array}{l}\mathrm{pH} \\
(1: 2 \text { soil : water suspension) }\end{array}$ & Potentiometry & Jackson (1973) \\
\hline $\mathrm{EC}\left(\mathrm{dSm}^{-1}\right)$ & Conductometry & Jackson (1973) \\
\hline Organic carbon $\left(\mathrm{g} \mathrm{kg}^{-1}\right)$ & Chromic acid wet digestion & Walkley and Black (1934) \\
\hline Available nitrogen $\left(\mathrm{kg} \mathrm{ha}^{-1}\right)$ & Alkaline Permanganate & Subbiah and Asija (1956) \\
\hline $\begin{array}{l}\text { Available phosphorus } \\
\left(\mathrm{kg} \mathrm{ha}^{-1}\right)\end{array}$ & Olsen's & Olsen et al., (1954) \\
\hline $\begin{array}{l}\text { Available potassium } \\
\left(\mathrm{kg} \mathrm{ha}^{-1}\right)\end{array}$ & $\begin{array}{l}\text { Neutral normal Ammonium } \\
\text { acetate }\end{array}$ & $\begin{array}{l}\text { Stanford and } \\
\text { English (1949) }\end{array}$ \\
\hline
\end{tabular}


Table.2 Influence of crop geometry, age and number of seedlings on nitrogen uptake $\left(\mathrm{kg} \mathrm{ha}^{-1}\right)$ at various growth stages of rice (Pooled analysis)

\begin{tabular}{|c|c|c|c|c|c|c|c|c|c|c|c|c|c|c|c|c|}
\hline \multirow[t]{2}{*}{ Treatments } & \multicolumn{4}{|c|}{ Tillering stage } & \multicolumn{4}{|c|}{ Panicle initiation stage } & \multicolumn{4}{|c|}{ Flowering stage } & \multicolumn{4}{|c|}{ Harvest stage } \\
\hline & $\mathbf{M}_{1}$ & $\mathbf{M}_{2}$ & $\mathbf{M}_{3}$ & Mean & $\mathbf{M}_{1}$ & $\mathbf{M}_{2}$ & $\mathbf{M}_{3}$ & Mean & $\mathbf{M}_{1}$ & $\mathbf{M}_{2}$ & $\mathbf{M}_{3}$ & Mean & $\mathbf{M}_{1}$ & $\mathbf{M}_{2}$ & $\mathbf{M}_{3}$ & Mean \\
\hline $\mathbf{S}_{1}$ & 20.8 & 22.1 & 24.2 & 22.4 & 71.6 & 76.9 & 70.6 & 73.0 & 96.5 & 110.1 & 98.3 & 101.6 & 106.3 & 109.8 & 102.9 & 106.4 \\
\hline $\mathbf{S}_{2}$ & 23.5 & 25.1 & 26.9 & 25.2 & 63.0 & 70.7 & 72.1 & 68.6 & 95.5 & 91.8 & 95.8 & 94.4 & 95.0 & 101.0 & 101.1 & 99.0 \\
\hline $\mathbf{S}_{3}$ & 26.9 & 27.9 & 32.9 & 29.3 & 59.2 & 71.0 & 77.1 & 69.1 & 78.1 & 88.3 & 99.2 & 88.5 & 78.8 & 90.5 & 109.8 & 93.0 \\
\hline $\mathbf{S}_{4}$ & 24.2 & 25.2 & 28.1 & 25.8 & 67.6 & 55.5 & 76.0 & 66.3 & 90.6 & 98.7 & 94.7 & 94.6 & 92.0 & 93.7 & 107.9 & 97.9 \\
\hline $\mathbf{S}_{5}$ & 26.8 & 29.9 & 30.4 & 29.1 & 59.6 & 72.7 & 83.2 & 71.8 & 79.7 & 102.0 & 113.1 & 98.3 & 81.9 & 107.9 & 116.3 & 102.0 \\
\hline$S_{6}$ & 26.2 & 34.1 & 36.1 & 32.1 & 49.9 & 70.7 & 76.1 & 65.6 & 71.6 & 88.7 & 99.4 & 86.5 & 72.9 & 90.8 & 103.5 & 89.0 \\
\hline \multirow[t]{2}{*}{ Mean } & 24.7 & 27.4 & 29.7 & & 61.8 & 69.6 & 75.8 & & 85.3 & 96.6 & 100.1 & & 87.8 & 98.9 & 106.9 & \\
\hline & $\mathbf{M}$ & $\mathbf{S}$ & $\begin{array}{c}\text { M at } \\
\mathbf{S}\end{array}$ & $\begin{array}{c}\text { S at } \\
\mathbf{M}\end{array}$ & $\mathbf{M}$ & $\mathbf{S}$ & $\begin{array}{c}\text { M at } \\
\mathbf{S}\end{array}$ & $\begin{array}{c}\text { S at } \\
\mathbf{M}\end{array}$ & $\mathbf{M}$ & $\mathbf{S}$ & $\begin{array}{c}\text { M at } \\
\mathbf{S}\end{array}$ & $\begin{array}{c}\text { S at } \\
\mathbf{M}\end{array}$ & $\mathbf{M}$ & $\mathbf{S}$ & $\begin{array}{c}\text { M at } \\
\mathbf{S}\end{array}$ & S at $M$ \\
\hline SEd & 0.7 & 0.9 & 1.5 & 1.5 & 1.5 & 1.8 & 3.2 & 3.0 & 1.9 & 2.1 & 4.2 & 4.1 & 2.2 & 2.5 & 4.6 & 4.4 \\
\hline $\mathrm{CD}(\mathrm{P}=\mathbf{0 . 0 5})$ & 1.8 & 1.7 & 3.3 & 3.0 & 4.2 & 3.5 & 6.9 & 6.1 & 5.3 & 4.8 & 9.1 & 8.3 & 6.2 & 5.2 & 10.2 & 8.9 \\
\hline$M_{1}-25 \times 25 \mathrm{~cm}$ & \multicolumn{5}{|c|}{$\mathrm{S}_{1}-14$ DOS + one seedling hill ${ }^{-1}$} & \multicolumn{5}{|c|}{$\mathrm{S}_{4}-21 \mathrm{DOS}+$ one seedling hill ${ }^{-1}$} & & & & & & \\
\hline$M_{2}-25 \times 20 \mathrm{~cm}$ & \multirow{2}{*}{\multicolumn{5}{|c|}{$S_{2}-14$ DOS + two seedlings hill ${ }^{-1}$}} & \multicolumn{5}{|c|}{$\mathrm{S}_{5}-21 \mathrm{DOS}+$ two seedlings hill ${ }^{-1}$} & & & & & & \\
\hline$M_{3}-25 \times 15 \mathrm{~cm}$ & & & & & $\mathrm{~S}_{3}-14 \mathrm{DOS}+$ three seedlings hill $^{-1}$ & \multicolumn{5}{|c|}{$\mathrm{S}_{6}-21 \mathrm{DOS}+$ three seedlings hill $^{-1}$} & & & & & & \\
\hline
\end{tabular}


Table.3 Influence of crop geometry, age and number of seedlings on phosphorus uptake $\left(\mathrm{kg} \mathrm{ha}^{-1}\right)$ at various growth stages of rice (Pooled analysis)

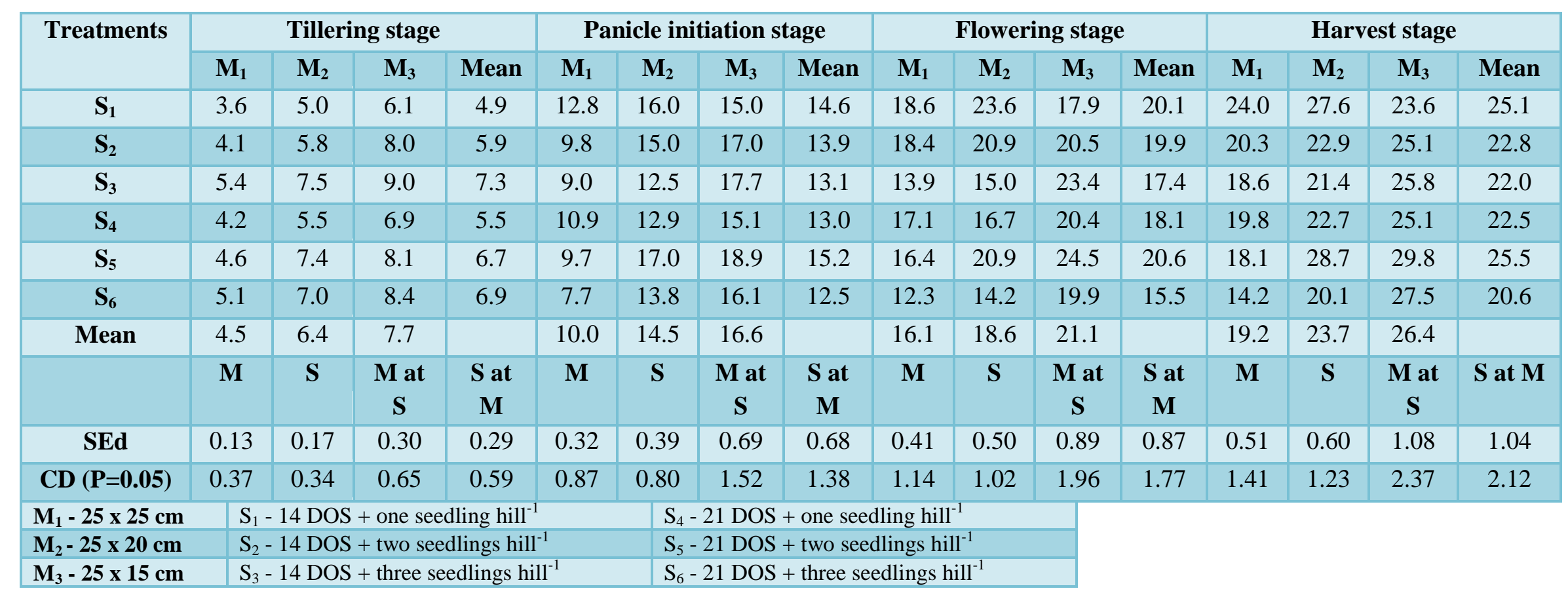


Table.4 Influence of crop geometry, age and number of seedlings on potassium uptake $\left(\mathrm{kg} \mathrm{ha}^{-1}\right)$ at various growth stages of rice (Pooled analysis)

\begin{tabular}{|c|c|c|c|c|c|c|c|c|c|c|c|c|c|c|c|c|}
\hline \multirow[t]{2}{*}{ Treatments } & \multicolumn{4}{|c|}{ Tillering stage } & \multicolumn{4}{|c|}{ Panicle initiation stage } & \multicolumn{4}{|c|}{ Flowering stage } & \multicolumn{4}{|c|}{ Harvest stage } \\
\hline & $\mathbf{M}_{1}$ & $\mathbf{M}_{2}$ & $\mathbf{M}_{3}$ & Mean & $\mathbf{M}_{1}$ & $\mathbf{M}_{2}$ & $\mathbf{M}_{3}$ & Mean & $\mathbf{M}_{1}$ & $\mathbf{M}_{2}$ & $\mathbf{M}_{3}$ & Mean & $\mathbf{M}_{1}$ & $\mathbf{M}_{2}$ & $\mathbf{M}_{3}$ & Mean \\
\hline $\mathbf{S}_{1}$ & 9.0 & 13.1 & 11.9 & 11.2 & 47.4 & 57.3 & 51.0 & 51.9 & 83.9 & 94.8 & 85.7 & 83.1 & 92.8 & 98.8 & 107.7 & 99.8 \\
\hline $\mathbf{S}_{\mathbf{2}}$ & 13.1 & 12.9 & 14.0 & 13.6 & 42.0 & 46.8 & 47.8 & 45.6 & 78.4 & 81.2 & 78.0 & 79.2 & 91.4 & 95.3 & 90.4 & 92.4 \\
\hline $\mathbf{S}_{\mathbf{3}}$ & 17.8 & 16.5 & 15.8 & 16.8 & 39.6 & 44.9 & 51.6 & 45.4 & 69.6 & 68.5 & 80.1 & 72.7 & 79.5 & 81.4 & 92.8 & 84.5 \\
\hline $\mathbf{S}_{4}$ & 11.8 & 12.1 & 14.6 & 12.9 & 38.9 & 42.0 & 53.4 & 44.7 & 80.0 & 72.5 & 93.1 & 81.9 & 89.1 & 88.5 & 107.0 & 94.9 \\
\hline $\mathbf{S}_{5}$ & 10.7 & 13.1 & 16.1 & 13.4 & 38.6 & 49.2 & 62.1 & 50.0 & 66.5 & 90.0 & 98.9 & 85.1 & 78.2 & 96.0 & 119.0 & 97.7 \\
\hline \multirow[t]{2}{*}{ Mean } & 12.5 & 14.1 & 15.0 & & 39.5 & 46.9 & 51.4 & & 72.0 & 77.9 & 84.3 & & 81.6 & 90.1 & 98.6 & \\
\hline & $\mathbf{M}$ & $\mathbf{S}$ & $\begin{array}{c}\text { M at } \\
\text { S }\end{array}$ & $\begin{array}{c}\text { S at } \\
\mathbf{M}\end{array}$ & M & $\mathbf{S}$ & $\begin{array}{c}\text { M at } \\
\text { S }\end{array}$ & $\begin{array}{c}\text { S at } \\
\mathbf{M}\end{array}$ & $\mathbf{M}$ & $\mathbf{S}$ & $\begin{array}{c}\text { M at } \\
\text { S }\end{array}$ & $\begin{array}{c}\text { S at } \\
\mathbf{M}\end{array}$ & $\mathbf{M}$ & $\mathbf{S}$ & $\begin{array}{c}\mathrm{M} \text { at } \\
\mathrm{S}\end{array}$ & $S$ at $M$ \\
\hline SEd & 0.3 & 0.4 & 0.8 & 0.7 & 1.0 & 1.2 & 2.1 & 2.0 & 1.6 & 2.0 & 3.5 & 3.4 & 1.9 & 2.2 & 4.0 & 3.9 \\
\hline $\mathrm{CD}(\mathrm{P}=0.05)$ & 0.9 & 0.9 & 1.6 & 1.5 & 2.7 & 2.4 & 4.5 & 4.1 & 4.5 & 4.0 & 7.8 & 7.0 & 5.4 & 4.6 & 9.0 & 8.0 \\
\hline
\end{tabular}


Table.5 Influence of crop geometry, age and number of seedlings on post harvest available N, $\mathrm{P}$ and $\mathrm{K}_{\text {status }}\left(\mathrm{kg} \mathrm{ha}^{-1}\right)$ of rice (Pooled analysis)

\begin{tabular}{|c|c|c|c|c|c|c|c|c|c|c|c|c|}
\hline \multirow[t]{2}{*}{ Treatments } & \multicolumn{4}{|c|}{ Nitrogen } & \multicolumn{4}{|c|}{ Phosphorus } & \multicolumn{4}{|c|}{ Potassium } \\
\hline & $\mathbf{M}_{1}$ & $\mathbf{M}_{2}$ & $\mathbf{M}_{3}$ & Mean & $\mathbf{M}_{1}$ & $\mathbf{M}_{2}$ & $\mathbf{M}_{3}$ & Mean & $\mathbf{M}_{1}$ & $\mathbf{M}_{2}$ & $\mathbf{M}_{3}$ & Mean \\
\hline $\mathbf{S}_{1}$ & 219.7 & 220.7 & 226.9 & 222.4 & 25.1 & 24.5 & 23.5 & 24.4 & 383.2 & 362.4 & 353.8 & 366.4 \\
\hline $\mathbf{S}_{2}$ & 234.3 & 228.7 & 228.6 & 230.5 & 26.6 & 25.2 & 25.0 & 25.6 & 381.4 & 365.8 & 370.6 & 372.6 \\
\hline $\mathbf{S}_{3}$ & 257.0 & 238.2 & 220.7 & 238.7 & 28.6 & 26.5 & 24.4 & 26.5 & 391.2 & 379.4 & 368.2 & 379.6 \\
\hline $\mathbf{S}_{4}$ & 238.3 & 235.3 & 222.4 & 232.0 & 27.4 & 26.0 & 24.8 & 26.1 & 381.9 & 369.3 & 354.4 & 368.5 \\
\hline $\mathbf{S}_{5}$ & 249.4 & 222.5 & 214.8 & 228.9 & 28.0 & 24.5 & 23.2 & 25.2 & 392.5 & 365.2 & 343.0 & 366.9 \\
\hline $\mathbf{S}_{6}$ & 257.6 & 237.9 & 227.3 & 240.9 & 30.5 & 26.6 & 25.8 & 27.6 & 411.3 & 379.8 & 385.8 & 392.3 \\
\hline \multirow[t]{2}{*}{ Mean } & 242.7 & 230.5 & 223.5 & & 27.7 & 25.5 & 24.5 & & 390.3 & 370.3 & 362.7 & \\
\hline & $\mathbf{M}$ & $\mathbf{S}$ & M at $S$ & $\mathbf{S}$ at $\mathbf{M}$ & $\mathbf{M}$ & $\mathbf{S}$ & $\mathbf{M}$ at $\mathbf{S}$ & $\mathrm{S}$ at $\mathrm{M}$ & $\mathbf{M}$ & $\mathbf{S}$ & $M$ at $\mathbf{S}$ & $\mathrm{S}$ at $\mathrm{M}$ \\
\hline SEd & 4.7 & 5.4 & 9.8 & 9.4 & 0.6 & 0.7 & 1.2 & 1.2 & 7.1 & 7.8 & 14.2 & 13.5 \\
\hline $\mathrm{CD}(\mathrm{P}=0.05)$ & 13.0 & 11.1 & NS & NS & 1.7 & 1.4 & NS & NS & 19.6 & 15.9 & NS & NS \\
\hline$M_{1}-25 \times 25 \mathrm{~cm}$ & \multicolumn{4}{|c|}{$\mathrm{S}_{1}-14 \mathrm{DOS}+$ one seedling hill ${ }^{-1}$} & \multicolumn{4}{|c|}{$\mathrm{S}_{4}-21 \mathrm{DOS}+$ one seedling hill ${ }^{-1}$} & & & & \\
\hline$M_{2}-25 \times 20 \mathrm{~cm}$ & \multicolumn{4}{|c|}{$\mathrm{S}_{2}-14 \mathrm{DOS}+$ two seedlings hill $^{-1}$} & \multicolumn{4}{|c|}{$\mathrm{S}_{5}-21 \mathrm{DOS}+$ two seedlings hill ${ }^{-1}$} & & & & \\
\hline$M_{3}-25 \times 15 \mathrm{~cm}$ & \multicolumn{4}{|c|}{$\mathrm{S}_{3}-14 \mathrm{DOS}+$ three seedlings hill ${ }^{-1}$} & \multicolumn{4}{|c|}{$\mathrm{S}_{6}-21 \mathrm{DOS}+$ three seedlings hill $^{-1}$} & & & & \\
\hline
\end{tabular}




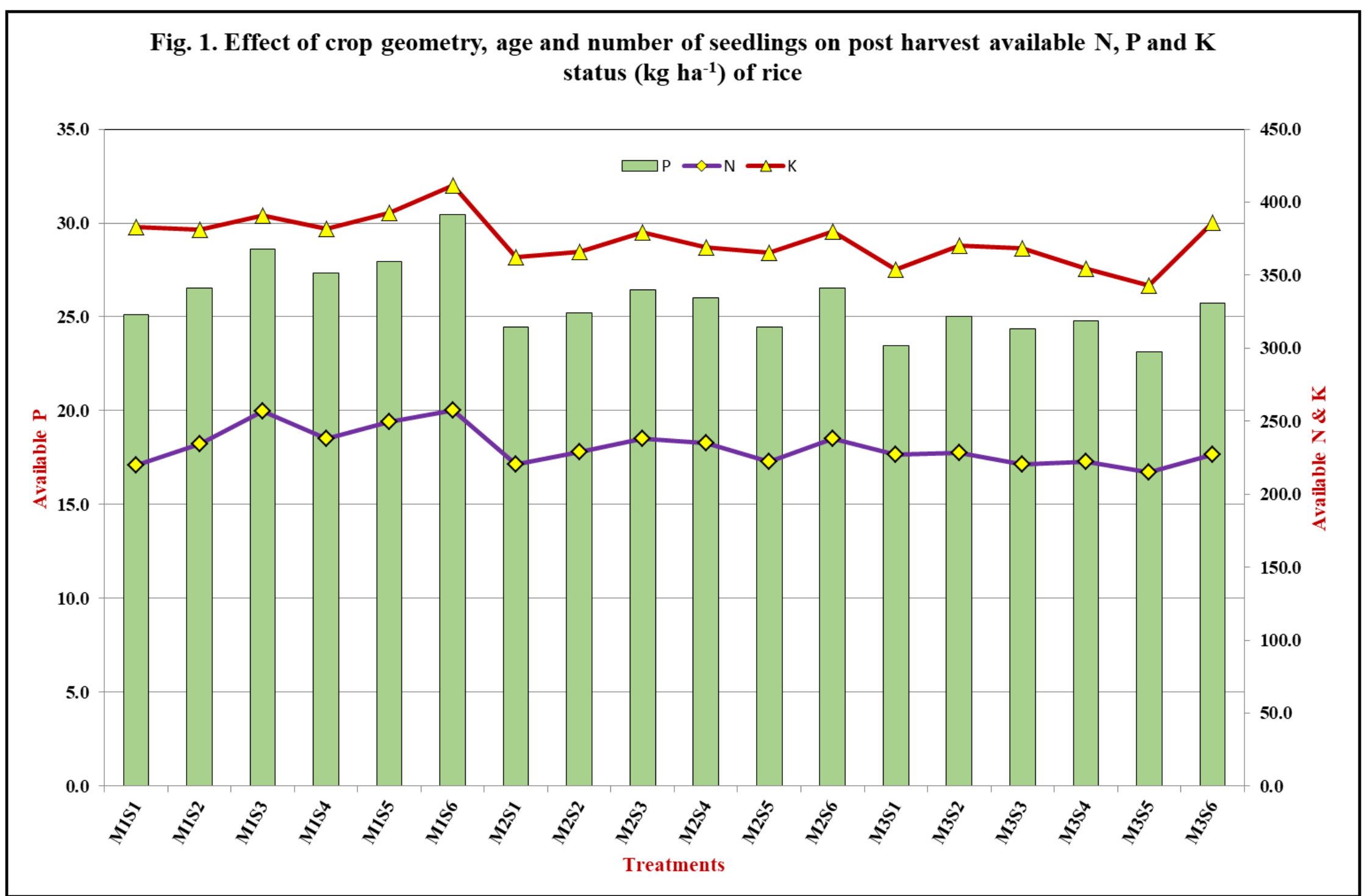




\section{Post harvest soil available nutrients (Table 5)}

Crop geometry showed a significant variation on available $\mathrm{N}$ in soil after harvest of rice. Higher values of available $\mathrm{N}$ were registered $\left(242.7 \mathrm{~kg} \mathrm{ha}^{-1}\right)$ under wider geometry of $25 \mathrm{x}$ $25 \mathrm{~cm}\left(\mathrm{M}_{1}\right)$ than $\mathrm{M}_{2}$ and $\mathrm{M}_{3}$. Closer crop geometry of $25 \times 15 \mathrm{~cm}\left(\mathrm{M}_{3}\right)$ registered the lowest soil available $\mathrm{N}\left(223.5 \mathrm{~kg} \mathrm{ha}^{-1}\right)$. The same trends were noticed in phosphorus and potassium too.

Age and number of seedlings treatments showed marked variations on soil available $\mathrm{N}$. During the experimentations, seedling age of 21 days with three seedlings hill ${ }^{-1}\left(\mathrm{~S}_{6}\right)$ left more available $\mathrm{N}$ in the soil (240.9 $\mathrm{kg} \mathrm{ha}^{-1}$ ) and superior over others. Transplanting of 14 DOS with one seedling hill ${ }^{-1}\left(\mathrm{~S}_{1}\right)$ observed the least soil available N (222.4 $\left.\mathrm{kg} \mathrm{ha}^{-1}\right)$. Similar results were found on $\mathrm{P}$ and $\mathrm{K}$.

Crop geometry had significant variations on post-harvest soil $\mathrm{N}, \mathrm{P}$ and $\mathrm{K}$ status during the study. Wider spacing of $25 \times 25 \mathrm{~cm}\left(\mathrm{M}_{1}\right)$ reported higher amount of available $\mathrm{N}, \mathrm{P}$ and $\mathrm{K}$ compared to others (Fig. 1). This might be due to lower plant population, comparatively less competition, reduced nutrient uptake and loss of these nutrients from the soil resulted in increased soil available nutrients. This is in accordance with the findings of Baskar (2009).

During investigation of the experiments, among the age and number of seedlings 21 day old three seedlings hill ${ }^{-1}\left(\mathrm{~S}_{6}\right)$ recorded higher soil available $\mathrm{N}, \mathrm{P}$ and $\mathrm{K}$ over others (Fig. 1). This might be due to poor root growth, less competition for light and lower nutrient absorption. Similar results were observed by Rajendran (2009). Available nutrient status gets depleted as a consequence of biomass production under best combination of non-monetary inputs (Bommayasamy et al., 2020). There was no significant interaction among treatment combinations on post-harvest soil available $\mathrm{N}, \mathrm{P}$ and $\mathrm{K}$ status.

\section{References}

Amit Kumar, B.P. Dhyani, Vipin Kumar, Ashish Rai, Arvind Kumar and Karamveer. 2018. Nutrient Uptake in Rice Crop as Influenced by Vermicompost and Nitrogen Application. International Journal of Current Microbiology and Applied Sciences. 7(3): 558-569.

Badawi, T.A. 2004. Rice-based Production Systems for Food Security and Poverty Alleviation in the Near East and North Africa. New Challenges and Technological Opportunities. FAO Rice Conference, held at Rome, Italy, 12-13 February 2004. In: http// www. fao. org. rice 2004/en/pdf.badawi.Pdf.

Barah, B.C. and Pandey, S. 2005. Rainfed rice production systems in Eastern India: An on farm diagnosis and policy alternatives. Indian Journal of Agricultural Economics 60, 110-136.

Baskar, P. 2009. Standardisaton of nursery techniques and crop geometry for rice under System of Rice Intensification (SRI). M.Sc. (Ag.) Thesis, Tamil Nadu Agric. Univ., Coimbatore, Tamil Nadu, India.

Bezbaruah, R., R.C. Sharma and P. Banik. 2011. Effect of nutrient management and planting geometry on productivity of hybrid rice (Oryza sativa L.) cultivars. American Journal of Plant Science. 2: 297-302.

Bommayasamy, N., L. B. Singh and F. H. Rahman. 2020. Effect of Planting Methods and Seedling Age on Growth, Yield and Nutrient Uptake in Rice under High Rainfall Areas of Bay Islands. International Journal of Plant \& Soil Science. 32(6): 96-102. 
Borkar, L.S., V.S. Khawale, P.B. Raut, T.S. Patil and H.S. Kolte. 2008. Studies on spacing and nitrogen management under System of Rice Intensification (SRI). Journal of Soil and Crops, 18(2): 438441.

Bufogle, A., P.K. Bollich, R.J. Norman, J.L. Kovar, C.W. Lindau, and R.E. Macchiavelli. 1997. Rice plant growth and nitrogen accumulation in drillseeded and water-seeded culture. Soil Science Society of America Journal 61: 832-839.

CPG. 2012. Crop Production Guide, Published by Department of Agriculture, Govt. of Tamil Nadu, Chennai and Tamil Nadu Agricultural University, Coimbatore. pp. 12-15.

Gobi, R, Chirom Surajkumar Singh, A. Balasubramanian, S. Sathiyamurthi and P.Stalin. 2018. Effect of nitrogen and spacing on grain yield and nutrient uptake of rice under SRI. Plant Archives 19(1): 750-752.

Jackson, M.L. 1973. Soil Chemical Analysis. Prentice Hall of India Pvt. Ltd., New Delhi, India.

Khan, A., M. Sarfaraz, N. Ahmad and B. Ahmad. 1994. Effect of $\mathrm{N}$ dose and irrigation depth on nitrate movement in soil and $\mathrm{N}$ uptake by maize. Agriculture Research. 32: 47-54.

Kumar, D. and Shivay, Y.S. 2004. System of rice intensification. Indian Farming, November, pp.18-21.

Manjunatha, B.N., R. Basavarajappa and B.T. Pujari. 2010. Effect of age of seedlings on growth, yield and water requirement by different system of rice intensification. Karnataka Journal of Agricultural Science 23(2): 231-234.

Nandhakumar, M.R., K. Velayudham and N. Thavaprakaash. 2016. Influence of crop geometry, age and number of seedlings on physiological characters in relation to yield of low land rice. Research on
Crops. 17 (1): 1-7.

Narayanappa, M., S. Thimmegowda, S.S. Reddy and O. Kumara. 2003. Influence of irrigation intervals and planting geometry on nutrient content and nutrient uptake in Davana. Karnataka Journal of Agricultural Science 16(4): 519-523.

Norman, R.J., D. Guindo, B.R. Wells and C.E. Wilson. 1992. Seasonal accumulation and partitioning of nitrogen-15 in rice. Soil Science Society of America Journal 56: 1521-1526.

Olsen, S.R., C.V. Cole, F.S. Watanabe and L.A. Dean. 1954. Estimation of available phosphorus in soils by extraction with sodium bicarbonate. Circular No. 939, USDA.

Piper, C.S. 1966. Soil and Plant Analysis. Hans publishers, Mumbai, India.

Rajendran, K. 2009. Evaluation of crop establishment techniques and weed management practices under System of Rice intensification. Ph.D. (Ag.) Thesis, Tamil Nadu Agric. Univ., Coimbatore, Tamil Nadu, India.

Sridevi, V. 2006. Relative contribution of individual components of system of rice intensification (SRI) to the yield of rice crop. M.Sc. (Ag.) Thesis, Pandit Jawaharlal Nehru College of Agriculture and Research Institute. Karaikal, Pondicherry, India.

Stanford, G. and L. English. 1949. Use of flame photometer in rapid soil test for $\mathrm{K}$ and Ca. Agronomy Journal. 41: 446447.

Subbiah, B.V. and G.L. Asija. 1956. A rapid procedure for estimation of available nitrogen in soils. Current Science. 25: 598-609.

Walkley, A. and C.A. Black. 1934. An examination of methods for determining organic matter and nitrogen in soils. Journal of Agricultural Science. 25: 598-609. 
Zheng, J., Lu, X., Jiang, X. and Tang, Y. 2004. The system of rice intensification (SRI) for super high yields of rice in Sichuan Basin. 4th International Crop
Science Congress, Brisbane, Australia, 26 September - 01 October, 2004. In http://www.ciifad.cornell.edu/ sri/countries.

\section{How to cite this article:}

Nandhakumar, M. R., K. Velayudham and Thavaprakaash, N. 2020. Nutrient Uptake and Soil Health as Influenced by Plant Density and Age of Seedlings of Rice (Oryza sativa L.) under Modified SRI Method of Planting. Int.J.Curr.Microbiol.App.Sci. 9(08): 2809-2822. doi: https://doi.org/10.20546/ijcmas.2020.908.316 